\title{
III. 安全性と質管理：理論と教育
}

\section{1. 医療安全・質管理の理論と実際 測ることができないものは良くならない}

\section{鮎澤＼cjkstart純子}

要旨

「質」「管理」「改善」についても「理論」がある。「PDCAサイクル」「測ることができないものは良くならな い」「継続的改善」といった考え方や具体的な手法を「理論」として整理しておくことは, 医療安全や質管 理における「実際」の実現に役立つ。医療安全と質管理は決して別物ではない.それどころか，医療安全 のその先にはまさに質管理，質改善があることを意識し，医療安全も質管理も，成果が視える取り組みに つなげていかなければならない.

〔日内会誌 $101 ： 3455 ３ 462 ， 2012$ ]

Key words 医療安全, 医療の質, 安全管理, 質管理, 質改善

はじめに

「質」「管理」「改善」についても, 取り組みの歴 史，特に一般の産業界の取り組みの歴史のなか で組み立てられた「理論」がある。そしてそれ らを応用し「医療の質管理」「医療の質改善」と して組み立てられた「理論」がある。

「医療の質」が語られるようになり, 改善への 取り組みも始まって久しいが，なかなか「あた りまえの取り組み」として医療界に広がっては こなかった。しかし，環境は変わりつつある。 気が付けば診療情報やDPCデータなどが電子化 されて収集されるようになりつつある。そして，
近年急速に進んでいる医療安全の管理体制と取 り組みは，あらためて「質」「管理」「改善」を理 解し, デー夕を活用し, さらなる医療安全, そ して医療の質の改善に向かう，またとないチャ ンスである。

第 1 章及び第 2 章では, インシデント・アク シデントの現状や診療の質の測定と改善に関す る取り組みの「実際」が紹介された。本稿では， 取り組みの実際の基本にある理論, なかでも「管 理」や「改善」に関する理論を中心に紹介し， 現場の「さらなる実際」につなげたい.

九州大学大学院医学研究院医療経営·管理学講座

Patient Safety and Quality of Medical Care. Topics : III. Management of Patient Safety and Quality of Medical Care : Theory and Practice ; 1 . Theories and practices of patient safety and quality management.

Junko Ayuzawa : Health Care Administration and Management, Graduate School of Medical Sciences, Kyushu University, Japan. 


\section{1.「管理」「改善」に関する基本的な理論と 実際}

（1）「管理 (management) する」ということ はどういうことか...「PDCAサイクルをまわすこ と」

「管理 (management)」については,「組織を指 揮し管理 (control) するための調整された活動」 など様々な定義があり，「管理する」ということ についても様々な説明ができることになるが, 何をさておきまずは「PDCAサイクルをまわすこ と」を挙げておかなければならない.

PDCAサイクルは, あらゆる管理の基本とされ ているものである．第二次世界大戦後に進んだ 品質管理の取り組みのなかでW. Edwards Demingらが提唱したもので, デミングサイクルとも 呼ばれている. PDCAサイクルという名称は, サ イクルを構成するPlan（計画）Do (実施) Check (点検・評価) Act（Action)（処置・改善）の 4 段階の頭文字をつなげたものである。この 4 段 階を，螺旋を描くように回し続ける（スパイラ ルアップする）ことで, 継続的改善が図られる ことになる（図 1).

（2）「測ることができないものは良くならな い」‥重要なのはCheck!

PDCAサイクルの 4 段階はいずれも重要である が, なかでも重要だとされているのがCheck(点 検・評価）である。点検・評価ができなければ, もしくは適切にできなければ, 次なる処置・改 善につながらないからである.「測ることができ ないものは良くならない」のである.

医療安全の取り組みで我々の現場は前より安 全になったのか. 前より質の高い医療を提供で きるようになったのか，そろそろそうした問い かけに応えられなければならないのではないか.

では，安全であれ質であれどのように評価す るか.ここがまさに, 安全と質の改善の実施に

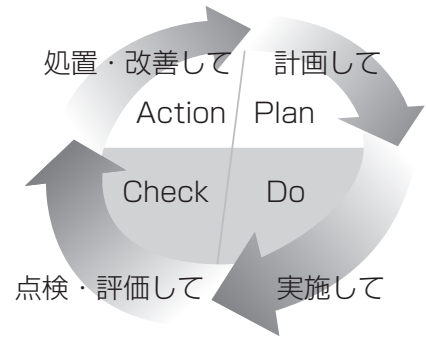

Plan (計画)：計画する

Do（実施）：計画に沿って実施する

Check (点検·評価): 実施が計画に沿つているか点検·評価する Act (Action) (処置·改善) : 計画に沿っていない点（問 題点）を調査し処置・改善する

図 1.PDCAサイクル

おける課題であり，本特集で「測定」として， 「インシデントレポート」や「臨床指標 (Quality Indicator)」の活用などが論じられているのであ る.

当然ながら, Plan（計画）の段階で, Check (点検・評価)の方法を検討しておかなければな らないことになる。医療安全の取り組みでいう なら，再発防止策をたてた後，その防止策が本 当に実施されているか，本当に間違いや事故を 減らしているのかをどのように検証するのかを 決めておかなければならないことになる。それ を決めておかないと，その防止策を継続するの か中止するのかも決められないことになる.

Check (点検・評価)にあたっては, 慎重な検 討が必要である. 計画が悪いのかもしれないし, 計画は良くても実施が悪いのかもしれない.「計 画の見直し」とょく言われるが,「実施の見直し」, 例えば資源を投入するなどの工夫で解決できる ことがあることにも注意しなければならない． ちなみに, Demingは, 後に, Check (点検・評 価）については充分に慎重な検討が必要である ということを強調するため, CheckをStudyに置 き換え, PDSAサイクルと称するようにもなって いる. 


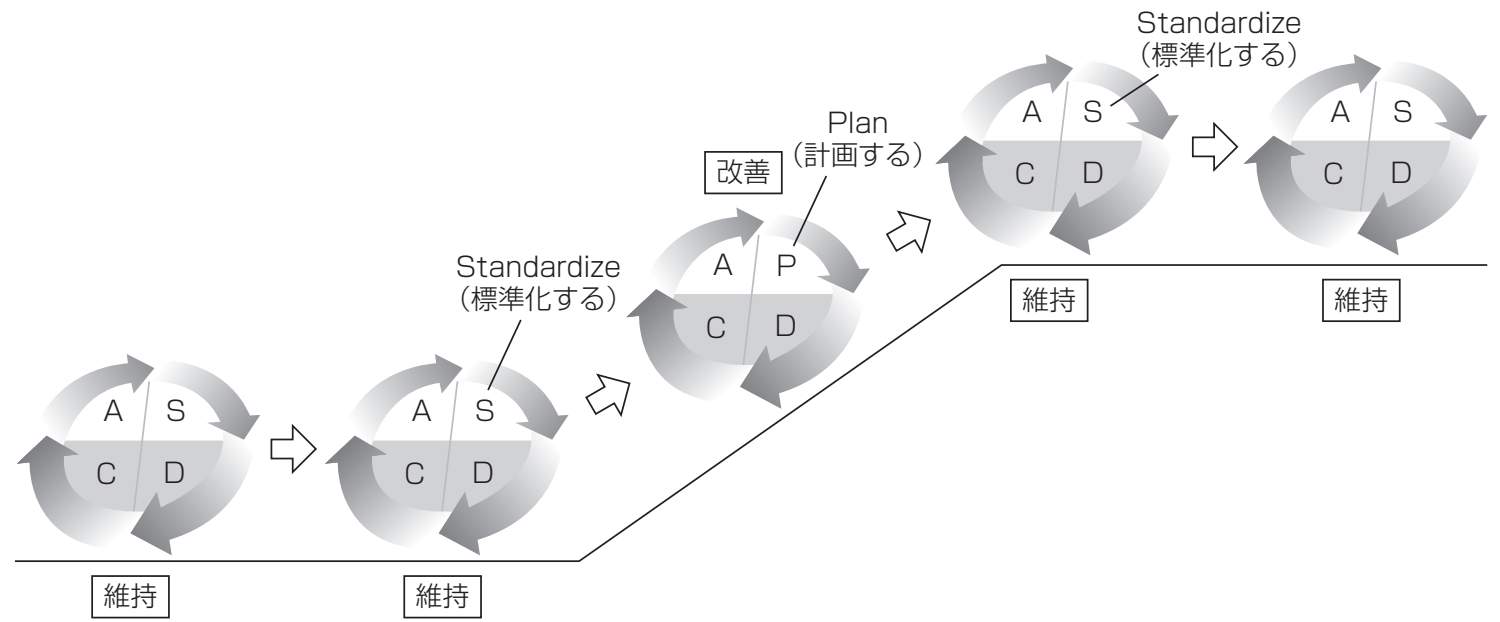

図 2.「改善のPDCAサイクル」と「維持のSDCAサイクル」による継続的改善

（3）「改善のPDCAサイクル」と「維持のSDCA サイクル」

「PDCAサイクル」と, CheckをStudyに置き換 えた「PDSAサイクル」を紹介したが，もうひと つ，PlanをStandardize（標準化）に置き換えた 「SDCAサイクル」も紹介しておかなければなら ない.

より高いレベルを目指し，新しい業務プロセ スを計画し（Plan），実施する（Do）。結果を評 価し(Check or Study)，出てきた不具合を修正 しながら処置・改善 (Act) を図り，一定の水準 を確保できる手順を見極め, 標準化 (Standardize）を図る。マニュアルやルールや手順書, 医 療の現場であればガイドラインやクリニカルパ スなどで標準化された方法を実施し業務プロセ スの精度をあげていく（さらなるStandardize）な かで，より高いレベルにしようとするとき，ま た新しい計画をたてていくことになる（さらな るPlan)。要は,「改善のPDCAサイクル」と「維 持のSDCAサイクル」を交互に回し続けていくこ とが継続的改善ということになる. 安全と質の 改善には標準化が欠かせないからこそ,この PDCAサイクルとSDCAサイクルのイメージ, そ して改善と維持という二つの局面のイメージを
つかんでおきたい（図 2).

（4）「継続的改善 (continual improvement)」を どのように進めるか

では, PDCAサイクルやSDCAサイクルをまわ す継続的改善は，具体的にどのように進めてい けばいいのだろうか. ISO9000では,「継続的改 善 (continual improvement)」を「要求事項を満 たす能力を高めるために繰り返し行われる活動」 と定義し,「組織の総合的パフォーマンスの継続 的改善を組織の永遠の目標とすべきである」と して「品質マネジメント 8 原則」を挙げている (表 1)（表 2) ${ }^{1}$.

なお，「継続的 (continual)」は「連続的 (continuous)」とは異なることを確認しておきたい. 常に大きく改善し続けなければならないという のではなく, 維持と改善という局面を繰り返し ながら続けるというところが重要なのである.

PDCA（SDCA）サイクルの 4 段階を基本にし た継続的改善の考え方や進め方は，これまで第 1 章・第 2 章で述べられた現場の実際とも重なる はずである.

（5）「質改善」の取り組みにおける考え方

「品質マネジメント 8 原則」を踏まえ，あらた めて質改善の取り組みにおけるポイントとなる 
品質マネジメントシステムを継続的に改善する目的は, 顧客及びその他の利害関係者の満足を向上させる 可能性を高めることである. 改善のための活動には, 次のものがある.

a）改善の領域を明らかにするために, 現状を分析し, 評価する.

b) 改善の目標を設定する.

c）その目標を達成するために可能な解決策を探す.

d）これらの解決策を評価し, 選定する

e）選定した解決策を実施する.

f）目標が満たされたかどうかを判定するために，実施結果を測定し，検証し，分析し，評価する.

g) 変更を正式なものとする.

必要であれば,より一層の改善の機会を明らかにするために, 改善の結果をレビューする.このように改善 は継続的な活動である.顧客及びその他の利害関係者からのフィードバック，並びに品質マネジメント システムの監査及びレビューも, 改善の機会を明確にするために利用できる.

\section{表 2. ISO 9000 で説明される「品質マネジメントの原則」}

原則 1 : 顧客重視：組織は, その顧客に依存しており, そのために, 現在及び将来の顧客二ーズを理解し, 顧客要求事項を満たし，顧客の期待を超えるように努力することが望ましい.

原則 2 : リーダーシップ: リーダーは, 組織の目的及び方向を一致させる.リーダーは, 人々が組織の目標 を達成することに十分に参画できる内部環境をつく(創) りだし，維持することが望ましい．

原則 3 : 人々の参画 : すべての階層の人々は, 組織にとって最重要なものであり, その全面的な参画によって, 組織の便益のためにその能力を活用することが可能となる.

原則 4 : プロセスアプローチ：活動及び関連する資源が一つのプロセスとして運用管理されるとき，望まれ る結果がより効率よく達成される.

原則 5 : マネジメントへのシステムアプローチ：相互の関連するプロセスを一つのシステムとして明確にし, 理解し, 運営管理することが組織の目標を効果的で効率よく達成することに寄与する.

原則 6 : 継続的改善：組織の総合的パフォーマンスの継続的改善を組織の永遠の目標とすることが望ましい.

原則 7 : 意思決定への事実に基づくアプローチ: 効果的な意思決定は, データ及び情報の分析に基づいている.

原則 8 : 供給者亡の互恵関係 : 組織及びその供給者は相互に依存しており, 両者の互恵関係は両者の価值創 造能力を高める。

考え方を確認しておきたい. 医療安全の取り組 みにおけるポイントとなる考え方でもある.

\section{(1)質第一}

「継続的改善を組織の永遠の目標とすべきであ る」としているように，質の改善を図るには「質 の向上なくして組織の存続はありえないという 姿勢」で臨まなければならないとされる，質と コスト，質と時間など，質第一かどうかを試さ れる場面には事欠かない. そもそも「質第一」安 全第一」という言葉がなければならないほど, 油断をするとあっという間にトレードオフされ 「第一」から「第二」になってしまうほど危うい のが「質」であり「安全」であることも心して おく必要がある。
(2)顧客志向‥ところで「顧客」は誰か

患者第一といいながら, 質や安全についても, 気が付けば医療従事者が自分たちで，そして自 分の都合で，あれこれ決めてしまってはいない だろうか. 加えて医療機関にとっての顧客とは 誰か. 患者だけではなく, 家族, 利用者, 地域 住民, 関連医療機関, 取引先といった多くの外 部顧客を意識しておかなければならない.また, 職員という内部顧客も忘れてはならない. 必要 に応じてPDCAサイクルのCheckに顧客の視点を 組み込むべきであるとされていることは,「患者 満足度」「従業員満足度」などが指標になってい ることと重なることになる．

(3)リーダーシップ

質の改善には組織的な取り組みが必要になる. 
いうまでもなくリーダーシップが久かせない. 掛け声だけではなく，質第一を実現できる環境 をつくること，現場の職員が質第一で動けるよ うな環境をつくること，そして一見相反するよ うに見える質の高い医療と効率の良い医療の両 方を実現する方法を見出すことにも，リーダー シップが発揮されることになる.

(4)全員参加

リーダーシップのもと, 組織横断的に, 職種 横断的に，取り組むことになる。ただし，「全員 参加」は「みんな一緒に同じことをする」とい うことではない.「それぞれの立場で質第一に向 かって取り組む」ということである.

改善について研修で話を聞いても，具体的に 何をどのようにすればいいのか，すぐにはわか らない.わからないものにはなかなか取り組め ない. 全員参加に向けて, 職員が質改善とは何 かを理解するためには，とにもかくにも具体的 な取り組み事例と成功事例を組織のなかに作り 出すことである．取り組みへの参加を説き伏せ るのにエネルギーを使うより, 場合によっては, やる気のあるメンバーで取り組んで成果をあげ てしまう, 部署単位や職種単位など機動力のあ る単位でまずは取り組んでさっさと成果をあげ てしまう。というのも現実的な方法のひとつで ある. その過程と結果が何よりの職員教育にな るはずである。成功して，広げていけばいい．

(5)プロセスアプローチ…「いプロセスがよ い結果を生む」「質をプロセスに織り込む」

質改善において，一般の産業界においては， 早くからプロセスアプローチが重要だとされて きた。一般の産業界においても, 事故やエラー などの原因を検討していくと人の問題に突き当 たることは少なくない. しかし，人を変えるの は難しい.「改善しやすいのは人よりプロセスで ある」という視点から, そして「そのエラーは エラーが起きやすいような手順や環境の結果で ある」という考え方から，「よいプロセスがよい
結果を生む」として，よいプロセスの設計に力 を注いできたのである，不具合な製品を市場に 出さないために重要なのは, 最後の検品で不具 合な製品を正確にはじくことではなく，そもそ も不具合な製品をつくりださないことであると して，「質をプロセスに織り込む」ともいわれて いる.

医療の質の評価については「構造 (Structure)」 「過程 (Process)」「結果 (Outcome)」が知られて いるが,「過程 (Process)」の評価, そして近年の 医療安全における事故防止の取り組みの姿勢も, 同様のアプローチである.

(6)システムアプローチ…医療システムの特徵 を理解する

医療安全においても「システムで防止する」と いうことが言われるようになってきた。医療現 場の業務をシステムという視点から検討できる ようになったことは近年の事故防止や安全管理 の極めて重要な進歩である.だからこそ，あら ためて医療システムの特性を整理しておかなけ ればならない.

・適応型システム (adaptive system)

システムは「機械的な性格をもった機械型シ ステム (mechanical system)」と「状況に応じて 自ら適応していく適応型システム (adaptive system)」という分け方ができるという ${ }^{3)}$. また，複 雑な適応型システムは,「『構成要素』(医療シス テムでいえば人間が含まれる）に，ある刺激に 対して極めて多様な, 基本的に予測不能な反応 を起こせる自由度がある。このために突発的で 予想外の, 時に創造的なふるまいが生じる可能 性が当然のこととしてある.こうした振る舞い は（中略）革新につながる場合もあればエラー を生むものにもなりうる.」3)という.これらの複 雑な適応型システムの特徵はまさに医療システ ムの特徵である。こうした医療システムの特徽 を踏まえたアプローチが必要であることは，次 項の「医療安全・質管理とヒューマンファクター」 


\section{トピックス}

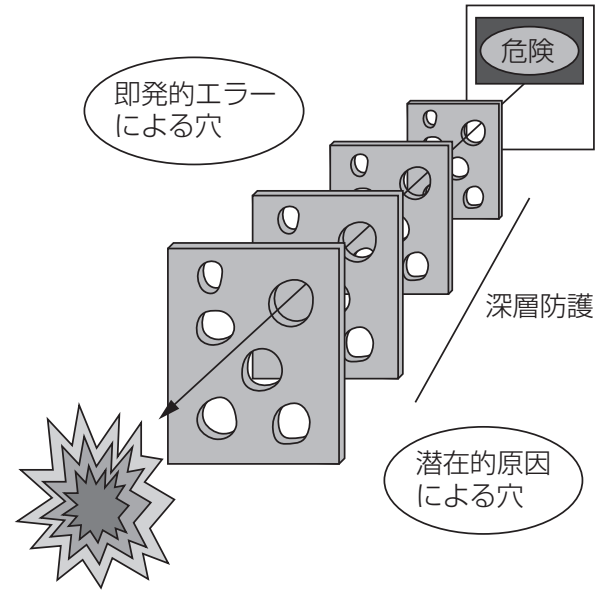

図 3. スイスチーズモデル

で論じられることになる.

\section{・スイスチーズモデル}

スイスチーズモデルとは，穴あきチーズを完 全ではない防御壁に例え, 防御壁が設定されな がら起きる事故をモデル化したものである ${ }^{2)}$. 組 織には防御壁が幾重にも重ねられているので大 抵どこかで防ぐことができるが，いずれの防御 壁も完全ではないために，不幸にして穴が重な ると(次々見落とされると)，エラーが事故とし て顕在化してしまうことになる.処方を間違え, 電子カルテのアラートを見落とし, 処方監査で 見落とし, 調剤監查で見落とし, 与薬時に見落 とし，患者も見落とし…といった薬剂事故に代 表されるような, 多職種で構成される複雑な医 療システムのなかで起きる事故の構造をイメー ジすることができるため，医療界でも広く知ら れたモデルとなっている。 このようなモデルで 事故の構造をイメージしながら, 防御システム をどのように機能させていけばいいのかを検討 していくことになる（図3）.

(7)継続的改善‥「「はじまりは出来損ない」

これまで述べてきたように質改善の中心は継 続的改善である.PDCAサイクルとSDCAサイク ルをまわして継続的改善を続けていくのだから，
敢えて言えば「はじまりはすべて出来損ない」な のである，実施しながらより良いものにしてい くのである．だから「はじめた後」が大事なの である。

James Reasonはその著書「組織事故」のなか で,「事前に準備するフィードフォワードで作ら れたマニュアルやルールは, 事故やニアミスが 起きれば，常に『マニュアルやルールがなかっ た』か『適切なマニュアルやルールではなかっ た』ことが繰り返されることになり, 結局はフィー ドバックであらためて策定するか見直すことに なる」として，マニュアルやルールのそもそも の定めについても述べている4).

\section{(8)重点指向}

限られた資源であればなおさら，あれこれや るのではなく, 取り組むべき課題を定めて取り 組まなければならない。重大な課題から取り組 むのか, いち早く成果があがることがわかって いる課題から取り組むのか, その判断も重要で ある。ちなみに「選択と集中」とも重なる「重 点指向」は, 対象を選択してそれだけに取り組 むというのではなく，その他に分散していた資 源を集め選択した対象に集中して投入するとこ ろまで含めて「重点指向」である.

(9)標準化

質を上げていくのには,「平均点をあげる」だ けでなく「ばらつきをなくす」という標準化に 向けたアプローチも必要であるとされている. 医療の質も同様である. ガイドラインやクリニ カルパスやマニュアルやルールや手順書は, 標 準化に向けたツールであり, 起きた不具合を活 用し，より精度をあげていくための，さらなる 標準化に向けたツールである. 再度Standardize を掲げたSDCAサイクルを思い出しておきたい. 
表 3.「研究」と「改善」における測定の違い

\begin{tabular}{l|l|l}
\hline & \multicolumn{1}{|c}{ Measurement for research } & \multicolumn{1}{c}{$\begin{array}{c}\text { Measurement for learning and } \\
\text { process improvement }\end{array}$} \\
\hline $\begin{array}{l}\text { Purpose } \\
\text { Tests }\end{array}$ & $\begin{array}{l}\text { To discover new knowledge } \\
\text { One large "blind" test }\end{array}$ & $\begin{array}{l}\text { To bring new knowledge into daily practice } \\
\text { Many sequential, observable tests } \\
\text { Data }\end{array}$ \\
$\begin{array}{l}\text { Control for as many biases as possible } \\
\text { Gather as much data as possible, "just } \\
\text { in case" } \\
\text { Can take long periods of time to obtain } \\
\text { results }\end{array}$ & $\begin{array}{l}\text { Gather "just enough" data to learn and complete } \\
\text { another cycle } \\
\text { "Small tests of significant changes" accelerates } \\
\text { the rate of improvement }\end{array}$ \\
\hline
\end{tabular}

\section{2. 始まっている医療の質管理・質改善に 関する教育}

これまで医療従事者が体系的に学ぶ機会が必 ずしも準備されていなかった「質」「管理」「改善」 であるが，医療安全の取り組みが進むなかで， 医療安全に関する体系的な卒前教育や職員研修 が始まり，そのなかで「質」「管理」「改善」など についても体系的な教育が始まってきた（第 4 項及び第 5 項参照).

WHOが発表した医療安全教育に関する医学部 生向けカリキュラムガイド (Patient Safety Curriculum Guide for Medical Schools : 2009) ${ }^{5)}$, 及 びその後発表された多職種向けカリキュラムガ イド (Multi-professional Patient Safety Curriculum Guide（以下カリキュラムガイド）：2011) ${ }^{6)}$ のなかでは, 医療安全という観点から学ぶべき とされる 11 項目のなかに, Topic 7 として「診 療の質を改善するために質改善の方法論を活用 すること」が織り込まれている。また，なぜ学 ばなければならないかという理由として,「研究 における測定と改善における測定は異なること」 「研究の方法論では現場の改善ができないこと」 を挙げ，「改善には改善の科学が必要である」と してその考え方を整理し，質改善において活用 されているツールが紹介されている.
（1）「研究における測定」と「改善における測 定」の違い

カリキュラムガイドでは,「研究においても改 善においてもいずれも科学的なアプローチが必 要である」としたうえで，だからこそ，研究と 改善において「測る」ことの意味が異なること を対比させて理解させようとしている。 この意 味の違いは時に現場の取り組みにおける誤解の ポイントになっていることでもあり，その違い をあらためて整理しておくことは研究者であり， 実務者でもある医療従事者にとっても重要であ る.

「目的」については，「研究」が「新しい知見 を得ること」としているのに対し,「改善」は 「新しい知見を日常の業務に導入すること」とし ている.「データ」については，「研究」が「必 要に応じて(“just in case”)できるだけ多くのデー 夕が必要である」としているのに対し「改善」は 「学ぶことができて次のサイクルを動かしていく ために十分な (“just enough”)データがあればい い」としている。そして，「取り組みの期間」に ついては,「研究」が「結果を得るために長い期 間が必要なことがある」としているのに対し， 「改善」では「小規模な取り組みで意義ある成果 を挙げていくことが改善の速度をあげていく」と していることに注目しておきたい（表 3).

（2）紹介されているッール

ツールについては,「パレート図」「ヒストグラ 


\section{表 4. 学ぶべき質改善の手法として挙げられて いる項目}

Quality improvement methods, PDSA cycle, change concept, continuous improvement methods, variation, CPI (Clinical Practice Improvement), RCA (root cause analysis), flowchart, Cause and effect diagram (ishikawa/fishbone), Pareto charts, histograms, run charts

ム」「特性要因図」といった「QC (Quality Control) 七つ道具」といわれる代表的な質改善のツール のほかに, 医療安全の取り組みの中で現場での 活用が始まっている事故事例の分析モデルであ るRCA (Root Cause Analysis) やFMEA (Failure Mode Effect Analysis) なども, 学ぶべき改 善のツールとして紹介されていることにも注目 しておきたい（表 4).

おわりに

「‥なるほど，そういうことだったのか！」‥ 大学院で経営・管理を学ぶ医師をはじめとする 医療系社会人院生の多くが, 「医療管理学」「病院 管理論」「医療安全管理論」といった科目のなか で「質」「管理」改善」などに関する理論や実践 の方法論を体系的に学んだ後で口にする. 現場 の取り組みの試行錯誤を通して自らつかんだ極 意ともいうべき方法論がすでに理論化されてい たり，なかには名前がついていたりするものも あることを知って, 少々がっかりしつつ, しか し間違いではなかったとことに納得する院生も 少なくない.そして, 理論はあくまでも理論で あるものの, 知っていればもっとうまく取り組 めたかもしれない, そして職員が皆同じような 知識をもっていればもっと早く進めることがで きたかもしれないとも口にする，学生達は卒前
教育で学び始めている，現場においては，医療 安全に関する職員研修が, これまで整理して学 ぶ機会のなかった「質」管理」「改善」に関する 「理論」を職員全員で学ぶ絶好の機会となるはず である。

あらためて, 医療安全と質管理が決して別物 ではないこと，医療安全のその先にはまさに質 管理，質改善があることを確認しておきたい. 「前より安全になったのか」前より質は向上した のか」という問いかけに応えなければならない. 質管理に医療安全の取り組みの見直しのヒント が見つかるはずである。医療安全の取り組みを 使って質管理に発展させることができるはずで ある，安全であれ，質であれ，成果が視える取 り組みが期待されているなか, 最後にもう一度, 「測ることができないものは良くならない」.

著者のCOI (conflicts of interest) 開示 : 本論文発表内容に 関連して特に申告なし

\section{文献}

1）一般財団法人日本規格協会, 品質マネジメントの原則, 一般財団法人日本規格協会ホームページ, http://www. jsa.or.jp/stdz/iso/pdf/qmp.pdf\#search= '品質マネジメン ト原則’ (最終アクセス 2012.11.14)

2) ジェームズ・リーズン：組織事故一起こるべくして起こ る事故からの脱出, 第 4 刷. 日科技連出版社, 東京, 2012 , 14-16.

3）米国医療の質委員会/医学研究所 : 医療の質一谷間を越え て 21 世紀システムへ, 第 1 版. 日本評論社, 東京, 2005 , 363-378.

4）ジェームズ・リーズン：組織事故一起こるべくして起こ る事故からの脱出, 第 4 刷版. 日科技連, 東京, 2001 , 116-120.

5) WHO : Patient Safety Curriculum Guide for Medical Schools 2009, http://www.who.int/patientsafety/educa tion/curriculum/download/en/index.html（最終アクセ ス 2012.11.14)

6) WHO : Multi-professional Patient Safety Curriculum Guide 2011, http://whqlibdoc.who.int/publications/201 1/9789241501958_eng.pdf（最終アクセス 2012.11.14） 